\title{
On the Different Views hitherto Proposed regarding the Morphology of the Flowers of Ginkgo biloba L.
}

(Preliminary note.)

By

Kenjiro Fujii, Rigakushi.

(Continued from No. 109, p. 15.)

With Pl. I.

The most noteworthy recent work including the general morphological questions of Ginkgo flower is Celakovsky's "Die Gymnospermen. Eine morphologisch-phylogenetische Studie." His views in regard to the morphology of Ginkgo flower are as follows:-The so-called seed-stalk of Ginkgo is a shoot that arises, as in Arancariacea, in the axil of a bract and serves as the flower-axis, producing usually two, but sometimes four decussate carpels. Each carpel is greatly reduced, its terminal portion being transformed, after the manner of Cycas, into a single ovule, and this terminal portion is alone developed; and very rarely (that is, in flowers with four ovnles) the stalk-like basal portions are seen. There occur, however, two-ovuled (then stalked) divided carpels; and this fact proves that the cup-shaped swelling at the base of the Ginkgo ovule is only an annular fold of the carpel, corresponding to that of the Cycas ovule ${ }^{(1)}$. Thus he considers the female flower as a real single flower. Further he cousiders the entire brachyblast of Ginkgo as an inflorescence, which is not closed to form a cone but open and diaphitic, and in which the subtending leaf of a flower is a normal foliage leaf (or a scaly leaf). He suggests also that the flowers of both sexes in "Proconiferce" were much more alike (the female nearly like the manyovuled, decussate, pleocarpellary variation of Ginkgo) and similarly

(1) “Referat," Bot. Zeitung, Jahrgang 49 (1891), p. 719. 
situated, that is, terminal to "brachyblasts" which originally produced flowers only; and that the carpels and stamens of the flowers of "Archigymnospermoe," from which the present Gymnosperma have been derived had marginal ovules (as Cycas) and pollen-sacs or small groups of pollen-sacs associated in numbers of $2-3^{(1)}$.

My own observations:-Numerous instances of progressive metamorphoses of different parts of floral organs are on record, but no instances of staminody and pistillody (carpellody, if I may use the term) of foliage leaves are found in chief literature of vegetable teratology. These unusual cases of anamorphosis, showing various steps of progressive metamorphoses are occasionally found in Ginkgo.

My observations were made chiefly on two old fermale Ginkgo trees in Shimoyama village, Minami-koma county in the province of $\mathrm{Kai}$, on the west bank of the river Fuji, and a male Ginkgo tree in Kami-yagisawa village, Nishi-yashiro county in the province of $\mathrm{Kai}$, on the east bank of the river. These two female trees ${ }^{(2)}$ produce ovules, and the male tree ${ }^{(3)}$ pollen-sacs, in the marginal portion of foliage leaves of the "Kurztriebe" as well as in their normal positions of the flower. Such abnormal formations of floral organs are found abundantly in these trees; but as a rule neither in every "Kurztrieb" of a branch, nor in every leaf of a "Kurztrieb." But often some of the leaves of a "Kurztrieb" produce such abnormal formations; and all the rest only show indications of such.

The number of ovules or pollen-sacs formed upon a single leaf varies from one to thirteen or more, and the formation of such ovules or pollen-sacs always takes place partly in expense of the tissue of the leaf, the margin of the latter being notched at the point of the formation. So in many cases the lamina of the leaf is almost entirely transformed into a group of ovules or pollen-sacs. The form of ovules or pollen-sacs is then very irregular and deformed, but when they are few in number and not crowded, it is generally the same with that of normal ones. 'The ovules and fruits formed upon the leaf are always smaller than normal

(1) Author's "Referat," Engl. J., XII., 1890, Lit.-Ber., p. 66-76.

(2) One of the two trees grows in the yard of the Buddhist temple Jōtakuji (上澤寺), and was found in July, 1891 by Mr. M. Shirai. The other tree grows in the yard of Honkokuji (本國寺), and was found by myself in Oct., 1891, during my journey to Shimoyama, intended for the closer observation of the female tree of Jotakuji, with the permission of the discoverer.

(3) The male tree was found on my second visit to Kai in April, 1892. 
ones and the micropyle is rather pointed, and also the pollen-sacs formed upon the leaf are in majority of cases smaller than the normal ones.

The ovule has often a longitudinal striation along the plane of the lamina of the leaf. It is more marked in the fruit (fig. 2 , g.), and corresponds to the prominent edges of the stony part of the seed, which is sharply pointed and smaller than a normal one. The ovule is partially enclosed at the base in a cup-shaped swelling just as in the normal ones, and this swelling gradually passes into the lamina of the leaf.

Often elongated outgrowth of the tissue is formed, instead of ovules or pollen-sacs of any definite form, mostly in the margin of the leaf for some length along the course of the veins of the leaf (fig. 1 and 4, e.).

Pollen-sacs developed at the margin of the leaf is neither arranged in any definite numbers, nor in any definite manner so as to form sori. As a rule no special terminal scale ("Endschuppe") is developed; but sometimes when an entire leat' is transformed into a stamen, the reduced lamina of the leaf assumes the form and position of the terminal scale. Pollen grains with proper number of cells are developed in the anther.

The petioles of leaves bearing ovules are of normal size, but those bearing pollen-sacs are often much reduced in length and thickness

Besides the staminody and carpellody of foliage leaves, various instances of multiplications and prolifications of floral organs are found in these same trees.

The flowers with 3-13 or more ovules, each of which is provided with its own stalklet are produced in abundance. The ovules are at first mostly alternate, but their position is usually disturbed during their subsequent growth.

Fig. 3 illustrates an interesting case. The flower-stalk is larger than that of a normal flower both in length and thickness. The ovules, each of which is raised on its own stalklet, are developed alternately along the common flower-stalk (the floral axis), but the uppermost (?) one has grown over the others. Moreover the flower-stalk (the floral axis) is terminated with a scaly bud, which decidedly disproves the foliar nature of the flower-stalk, though it was considered as a leaf-stalk by Van Tieghem.

Not only the flowers with a number of ovules provided with their own long stalklets are met with, but also flowers with a number of sessile ovules and several intermediate forms between such an abnormal flower and a normal two-ovuled flower. 
In "Kurztriebe" of weaker development, however, flowers with a single ovule with a rather slender stalk are often met with; and the cross sections of such a stalk sometimes show one or two fibrovascular bundles similarly situated as those of the petiole of the foliage leaf, while sections of the stalk of a normal two-ovuled flower show generally four bundles so arranged as to have two planes of symmetry. A flower-stalk with one or two fibrovascular bundles is therefore to be considered as equivalent to a leaf-stalk, the petiole of the carpellary leaf.

In the cross sections of the stalk of a many-ovuled flower we find, as a rule, as many fibrovascular bundles as the ovules; and each bundle divides into two in its course, previous to its entrance to the stalklet of each ovule; so that in a cross section of the stalklet we find a pair of fibrovascular bundles similary situated as those in the petiole of the foliage leaf.

Although a great number of specimens have been studied, no foliar structure like a bract has been found subtending the stalked ovule.

These facts together with the formation of ovules upon the foliage leaves, present a strong evidence of the foliar nature of the ovule, in accordance with the view of Van Tieghem, Eichler, Čelakovský, \&c., and contrary to the view of StrRasburger and others, who consider it as an organ of axial nature.

In the male flowers, stamens with three anthers are often met with. I have also found a brachyblast consisting of scaly leaves around the base and a male inflorescence, in which there is a single foliage leaf of weaker development.

As to the cause of the carpellody and staminody of the foliage leaves, I am not yet ready to express any definite opinion; but the multiplication and prolification of the floral organs are mostly associated with hypertrophy.

Conclusion :-1. The prominent edges of the stony part of the seed correspond to the margin of the carpellary leaf ; and that is why there are neither fibrovascular bundles, nor even any special cell rows found in them.

2. The ovule is an organ of foliar nature, and the cup-shaped swelling at its base is the reduced portion of the lamina of the carpellary leaf.

3. The anther is an organ of foliar nature, and its knob-like terminal scale ("Endschuppe") is the reduced portion of the lamina of the staminal leaf. 
108

4. The ovules and the anthers of Ginkgo are both marginal formations of sporophylls, though the anthers of Coniferce in general have hitherto heen often considered as organs developed on the under surface of staminal leaves.

5. The normal seed-stalk is the floral axis, whose apical bud is usually suppressed, and which bears only two rudimentary carpels.

6. The elongated stalklet of the ovule of Ginkgo cccasionally developed is not simple outgrowth, as has been considered by some authors, but is the petiole of the carpellary leaf developed alternately along the floral axis.

7. The normal fermale flower is not an inflorescence as has been considered by Strasburger and others, but a real single flower as considered by Eichler, Č́elakovskŕ, and others.

8. The disputed point in the homology of male and female flowers of Coniferce is thus clearly established as far as Ginkgo is concerned, as is seen when we compare a normal male flower and a female flower with a number of stalked ovules.

Remarks on the phylogeny of Ginkgo:-The view that among Coniferce Ginkgo comes nearest to Cycadacea has hitherto been of ten held on account of its lobed dichotomously veined leaf and drupaceous fruit. We may here briefly enumerate the points of resembrance between Ginkgo and Cycadacece, and especially Ginkgo and Cycas.

(a) The formation of ovules upon the foliage leaves of Ginkgo reminds us of the carpellary leaves of Cycas, and the ovules are on both genera marginal formations of the sporophyll.

(b) Drupaceous fruits of Ginkgo and Cycadacece much resemble ench other.

(c) The neck of archegonia consists in both Ginkgo and Cycadacece of two cells.

(d) The formation of the canal cell was formerly believed not to take place in Cycadacea, while it was well known in Ginkgo, and indeed in Coniferce in general; but it has been recently proved to take place in Cycas revoluta ${ }^{(1)}$.

(1) S. Ikeno. Vorläunge Mittheilung über die Canalzellbildung bei Cycas revoluta. Bot. Centralblatt. Bd. LXVII. No. 7, p. ${ }^{n} 193$ (1896).

S. Ikeno. Note préliminaire sur le Formation de la Cellule de Canal Chez le Cycas revoluta (With pl. V.). The Bot. Mag. Tōkyō, Vol. X, No. 115, Part II p. 63 (1896). 
(e) Long after Wiliendm Hofmeister wrote "in dessen [Pollenschlauch d. Coniferen] Innerem vielleicht Samenfäden sich bilden,"(1) spermatozoids have been found in Ginkgo biloba ${ }^{(2)}$ and $C^{y} y$ cas revoluta ${ }^{(3)}$ for the first time in 1896 ; and the behavior of their pollen in regard to the process of fertilization has been found to be similar ${ }^{(4)}$.

$(f)$ The "kurztrieb" of Ginkgo is exactly similar in all essential morpological points to the stem of Cycadacece; they are both usually unbranched, but sometimes copiously branched.

Thus we see that Ginkgo and $C y c a$ s is so near to each other that Ginkgo is more closely related to Cycas than to most other genera of Coniferce; but at the same time they deviate from each other in the following respects:-(a) In Cycas pollen-sacs are borne on the under surface of the staminal leaf, while in Ginkyo they are borne on the margin of the sporophyll; (b) Ginkgo has "langtriebe" and "Kurztriebe," while Cycas has "Kurztriebe" only; and their leaves are greatly different in form, habit, and structure; (c) the embryo of Ginkgo has no suspensor, while that of Cycas has one.

The formation of sporangia on the margin of leaves, the lobed dichotomously-veined leaves, and the formation of spermatozoids are the most remarkable points which Ginkgo and some ferns have in common.

Such a plant as Ginkgo might have been derived from some kind of F'erns, but not from Lycopodiacece, to which many other genera of Coniferce are closely related. In fact, Coniferce may be a heterogeneous group; and Ginkgo may be properly established as a distinct family among Gymnospermce, that stands between Cycadacece and Coniferce as one of the four main branches of Gymnospermo, but not as a connecting link between Cycadacea and Coniferce.

(Concluded.)

Botanical Institute, Science College, Imperial University, Tōkyō, Dec. 17th, 1896.

(1) Vergl. Untersuchungen u. d. Samenbildung d. Coniferen. p. 140 (1851).

(2), (4). S. Hirase. On the Spermatozoid of Ginkgo biloba (Japanese). The Bot. Mag. 'Tōkyō, Vol. X., No. 116, Part. I, p. 325.

(3), (4). S. Ikeno. On the Sprematozoid of Cycas revoluta (Japanese). The Bot. Mag. Tōkyō, Vol. X., No. 117, Part I, p. 367. 


\section{EXPLANATION OF PLATE I.}

Fig. 1. A female "kurztrieb." $a$ apical scaly bud; $b$ normal fenale flower; $c$ leaf bearing irregular outgrowths of tissue; $d$ leaf bearing ovules; $e$ irregular outgrowth of tissue; $f$ cup-shaped swelling at the base of the ovale; $g$ longitudinal striation of the pulpy portion of the seed.

Fig. 2. A foliage leaf bearing a ripe fruit. $g$ longitudinal striation of the pulpy portion of the seed.

Fig. 3. A female flower with an apical bud and a number of stalked ovules. $f$ cup-shaped swelling at the base of the ovule.

Fig. 4. A branched "Kurztrieb," in which the main axis $a$ and the branch $c$ are dead, and the branch $b$ only is alive. $d$ normal male flower; $e$ elongated irregular outgrowth of tissue; $g$ leaf bearing anthers; $h$ normal foliage leaf. 